\title{
Energy budget calculations indicate resource limitation in Eastern Pacific leatherback turtles
}

\author{
Bryan P. Wallace ${ }^{1,3, *}$, Susan S. Kilham ${ }^{1}$, Frank V. Paladino ${ }^{2}$, James R. Spotila ${ }^{1}$ \\ ${ }^{1}$ Drexel University, Department of Bioscience and Biotechnology, 3141 Chestnut Street, Philadelphia, Pennsylvania 19104, USA \\ ${ }^{2}$ Indiana-Purdue University, Department of Biology, 2101 East Coliseum Boulevard, Fort Wayne, Indiana 46805, USA \\ ${ }^{3}$ Present address: Duke University Center for Marine Conservation, Nicholas School of the Environment \\ and Earth Sciences, 135 Duke University Marine Laboratory Road, Beaufort, North Carolina 28516, USA
}

\begin{abstract}
Resource availability constrains energy allocations to competing functions such as growth and reproduction, and thus influences animal life-histories and population dynamics. Leatherback turtles Dermochelys coriacea are critically endangered and exhibit physiological and life-history traits unique among marine reptiles. In addition, leatherback nesting populations in the North Atlantic (NA) are, on average, larger, produce more eggs, exhibit shorter remigration intervals (RIs, time between nesting seasons), and generally demonstrate more stable population trends than Eastern Pacific (EP) nesting leatherback populations. In order to compare energy requirements of inter-basin leatherback populations, we estimated costs associated with reproduction to calculate the energy budgets of leatherback populations from the EP and the NA. Our estimations illustrate that in contrast to reported trends in RIs of these populations $(\mathrm{EP}=3.7 \mathrm{yr}$; NA $=2 \mathrm{yr})$, NA leatherbacks should require RIs between 1.5 to 4 times longer than their EP counterparts to accumulate sufficient energy to return to their nesting beaches for an entire reproductive season. These results indicate that resource limitation might lengthen RIs for EP leatherbacks compared to NA leatherbacks, thus decreasing the EP population's reproductive success and increasing its exposure to risk of fisheriesrelated mortality. We hypothesize that stochastic resource availability related to El Niño-Southern Oscillation (ENSO) is exacerbating the effects of high incidental fisheries mortality, resulting in plummeting EP leatherback populations. Therefore, management strategies for fisheries should allow little, if any, mortality of Pacific leatherbacks if there is to be any reasonable hope for recovery of this population.
\end{abstract}

KEY WORDS: Resource limitation · Energy budgets · Leatherback turtles · Population dynamics · El Niño-Southern Oscillation

Resale or republication not permitted without written consent of the publisher

\section{INTRODUCTION}

Allocations of time and energy to mutually exclusive functions (i.e. growth, activity, reproduction) are constrained by an animal's physiology, its environment, and by resource limitations (Dunham et al. 1989). Resources available to an individual animal are finite, and thus constrain resource allocation such that increased investment in reproduction necessarily results in decreased allocation to other components of the overall energy budget (Congdon et al. 1982). In marine ecosys- tems, climate and oceanographic processes that drive resource availability (i.e. El Niño-Southern Oscillation [ENSO], North Atlantic Oscillation [NAO]) can have profound impacts on marine animal populations (Stenseth et al. 2002) through constraints on energy budgets, and thus can influence body size, condition and growth (Wikelski \& Thom 2000), reproductive output (Limpus \& Nicholls 1998, Solow et al. 2002), and population dynamics (Trillmich \& Limberger 1985, Hays 1986, Schreiber \& Schreiber 1989, Jenouvrier et al. 2005). Therefore, studies of marine animal bioener- 
getics must account for the effects of environmentallydriven resource availability on resource allocation strategies and their consequences for marine animal life-history traits and population dynamics.

Leatherback turtles Dermochelys coriacea are critically endangered (Spotila et al. 2000), and inhabit almost every ocean from the subarctic to the tropics (Reina et al. 2002). Leatherbacks thermoregulate in varied thermal environments (Paladino et al. 1990), make epic migrations (Morreale et al. 1996, Eckert \& Sarti 1997, Ferraroli et al. 2004, Hays et al. 2004, James et al. 2005), have the fastest growth rate (Zug \& Parham 1996) and largest reproductive output (Reina et al. 2002) of any turtle, and are among the largest living reptile species (200 to $900 \mathrm{~kg}$ ). Further, leatherbacks are specialist predators for gelatinous zooplankton prey (Bjorndal 1997). Therefore, estimates of leatherback bioenergetics require quantification and understanding of the considerable energetic demands of the species' distinctive physiology, movements, and life-history.

In addition to the unique biological traits of leatherbacks as a species, distinct differences exist between leatherback populations from the Eastern Pacific (EP) and North Atlantic (NA) Ocean basins. NA leatherbacks, on average, are larger, more massive, have larger clutch sizes, and shorter remigration intervals (RIs; time period between subsequent nesting seasons) on average than their EP counterparts (Table 1; Van Buskirk \& Crowder 1994, Boulon et al. 1996, Reina et al. 2002, Dutton et al. 2005). Further, EP leatherback populations are in danger of becoming extinct within the next 20 yr (Spotila et al. 2000), whereas NA leatherback populations are stable or decreasing only slightly (Troëng et al. 2004), and some are increasing (Dutton et al. 2005). Such morphometric and reproductive traits as those enumerated above are influenced by resource quality and availability for sea turtles (Bjorndal 1982, Limpus \& Nicholls 1988, Hays 2000,
Solow et al. 2002, Broderick et al. 2003) and other reptiles (Congdon et al. 1982, Wikelski \& Thom 2000). For example, distinct patterns of seasonal and long-term reproductive output between populations of green turtles Chelonia mydas were attributed to differences in energy available from their respective diets (Bjorndal 1982). Moreover, climatically influenced variations in oceanographic conditions affect resource availability and thus population trends in sea turtles (Limpus \& Nicholls 1988, Solow et al. 2002). Such oceanographic fluctuations cause abundances and distributions of leatherback prey (e.g. jellyfish, ctenophores and other gelatinous animals) (Bjorndal 1997, James \& Herman 2001) to vary greatly in time and space (Mills 2001, Lynam et al. 2004).

The recent dramatic decline in global leatherback populations is chiefly due to extensive egg-harvesting and adult mortality due to direct hunting and incidental fisheries interactions within the leatherbacks' extensive range (see analyses by Spotila et al. 2000, Ferraroli et al. 2004, Hays et al. 2004, Lewison et al. 2004, Troëng et al. 2004, James et al. 2005, Kaplan 2005). However, effects of climatically altered resource availability on energy acquisition, which have not been considered in these analyses, may also have significant impacts on the viability of leatherback populations. In order for female leatherbacks to reproduce, they must harvest and store sufficient energy while foraging to facilitate egg production, nest construction, survival at sea between nesting events, and round-trip migration between foraging and nesting areas (Owens 1980). We combined costs of egg clutches and energy expenditure of terrestrial and at-sea activities associated with reproduction to calculate the reproductive energy budgets and estimated feeding rates necessary to meet energy costs for EP and NA leatherback populations. We interpret these results in the context of climatically influenced resource availability affecting the life history and population dynamics of this species.
Table 1. Dermochelys coriacea. Comparison of biological parameters of an Eastern Pacific (EP) population at Playa Grande, Parque Nacional Marino Las Baulas (PNMB), Costa Rica, and a North Atlantic (NA) population at Sandy Point National Wildlife Refuge, St. Croix, US Virgin Islands. CCL: curved carapace length; RI: remigration interval

\begin{tabular}{|lcccccc|}
\hline Area & $\begin{array}{c}\text { CCL } \\
(\mathrm{cm})\end{array}$ & $\begin{array}{c}\text { Mass } \\
(\mathrm{kg})\end{array}$ & $\begin{array}{c}\text { Clutch size } \\
(\text { no. eggs })\end{array}$ & $\begin{array}{c}\text { RI } \\
(\mathrm{yr})\end{array}$ & $\begin{array}{c}\text { Population } \\
\text { status }\end{array}$ & Source \\
\hline $\begin{array}{l}\text { PNMB } \\
\text { (EP) }\end{array}$ & $123-170$ & $196-308^{\mathrm{a}}$ & 64.1 & 3.7 & Decreasing & $\begin{array}{l}\text { Reina et al. } \\
(2002)\end{array}$ \\
$\begin{array}{l}\text { St. Croix } \\
\text { (NA) }\end{array}$ & $131-177$ & $259-506$ & 79.7 & $2-3^{\mathrm{b}}$ & $\begin{array}{c}\text { Stable or } \\
\text { increasing }\end{array}$ & $\begin{array}{l}\text { Boulon et al. } \\
\text { (1996) }\end{array}$ \\
$\begin{array}{l}\text { aWeighed in 2002 to 2004 } \\
\text { b91.7\% remigrant turtles }\end{array}$ & & & & & \\
\hline
\end{tabular}

\section{MATERIALS AND METHODS}

We estimated the total leatherback reproductive energy budget for both EP (Playa Grande, Parque Nacional Marino Las Baulas [PNMB], Costa Rica) and NA (Sandy Point National Wildlife Refuge, St. Croix, US Virgin Islands) populations. These populations have been studied extensively since the 1980s (Boulon et al. 1996, Spotila et al. 2000, Reina et al. 2002, Dutton et al. 2005).

We used mass-specific metabolic rates (Paladino et al. 1990, 1996) and 
durations (Reina et al. 2002) of each phase of the nesting process, average clutch sizes (Boulon et al. 1996, Reina et al. 2002), and data on energy content of reptilian eggs (Schmidt-Nielsen 1997) to estimate energy costs of nesting events and egg clutches for each population. Although the estimated clutch frequency (ECF) was not reported for St. Croix leatherbacks, we assumed that clutch frequencies between the 2 populations were similar because PNMB leatherback ECFs were consistently 1 to 2 nests greater than observed clutch frequencies (OCF) (Reina et al. 2002), and the St. Croix OCF was 5.26 (Boulon et al. 1996). To estimate energy expenditure during internesting periods, we used the mean field metabolic rate (FMR) $\left(0.40 \mathrm{~W} \mathrm{~kg}^{-1}\right)$ reported by Wallace et al. (2005). We estimated travel rates, distances and durations of round-trip migrations as being approximately $4000 \mathrm{~km}$ each way at $70 \mathrm{~km} \mathrm{~d}^{-1}$ for both EP (Morreale et al. 1996, Eckert \& Sarti 1997, Eckert 2002, G. L. Shillinger et al. unpubl. data) and NA (Ferraroli et al. 2004, James et al. 2005) populations, and assumed that leatherbacks migrated away from the tropics to high-latitude areas to forage. Because leatherbacks are probably more active and spend more time during migration and foraging in colder waters associated with higher-latitude pelagic areas than in coastal, neritic habitats occupied during the nesting season (James et al. 2005), we assumed that the FMR during migration and foraging is closer to the maximum FMR (0.74 $\mathrm{W} \mathrm{kg}^{-1}$ ) reported by Wallace et al. (2005). We calculated daily maintenance costs while on foraging grounds by assuming that this maximum FMR value included all regulatory processes (e.g. thermoregulation, osmoregulation, digestion, assimilation, vitellogenesis) and activity (e.g. diving, prey handling) costs. We also assumed that leatherbacks do not forage during their nesting season but instead rely on fat stores accumulated while foraging (Owens 1980). This assumption is corroborated by (1) the remarkable difference in body mass between leatherbacks on their foraging grounds versus that on their nesting grounds ( 33\% heavier on foraging grounds), which indicates that leatherbacks probably catabolize fat reserves to fuel migration and reproduction, and thus are fasting while on their nesting grounds (James et al. 2005), and by (2) videos of internesting female leatherbacks at PNMB, which indicated that they swim past small jellyfish without feeding (Reina et al. 2005). We then used the equation:

$$
\mathrm{RE}=N+E+I+M
$$

where $N=$ nesting activity, $E=$ egg clutches, $I=$ internesting periods, and $M=$ migrations to and from PNMB or St. Croix to calculate total reproductive energy (RE) cost for a female leatherback.

In order to estimate the energy intake necessary for reproduction, we first used literature values for leatherback prey energy content $\left(310 \mathrm{~kJ} \mathrm{~kg}^{-1}\right.$ wet mass; Davenport \& Balazs 1991) and estimated feeding rates for leatherbacks observed while foraging at or near the surface $\left(\sim 200 \mathrm{~kg} \mathrm{~d}^{-1}\right)$ (Duron 1978 [as cited in Davenport \& Balazs 1991]). We then calculated the total prey biomass necessary for RE, subtracted prey biomass necessary to meet foraging costs (at FMR = $0.74 \mathrm{~W} \mathrm{~kg}^{-1}$ ), and divided this by the prey biomass remaining at different feeding rates. We conservatively assumed $80 \%$ assimilation efficiency, based on measurements for slider turtles Trachemys scripta (Avery et al. 1993) fed a diet of similar protein content to that of pelagic jellyfish (Malej et al. 1993) and given the high digestion rate of gelatinous prey in fishes (Arai et al. 2003).

To investigate the hypothesis that inter-basin differences in resource availability could result in differences between EP and NA leatherback populations, we created a simple model to estimate the energetic costs incurred and the daily feeding rates necessary to meet reproductive energy requirements during lengthened RIs for both EP and NA leatherbacks. First, we added foraging and maintenance costs to RE and divided this cost per egg laid per reproductive season for a given RI. We then calculated the daily feeding rates necessary to accrue sufficient energy for reproduction for different RI lengths. By doing so, we determined how the costs of reproduction and foraging and feeding rates necessary to meet these costs varied with RI length in both populations. For clarification, we estimated foraging and maintenance costs during the interval beginning at the end of Nesting Season 1 and ending at the beginning of Nesting Season 2, not during the round-trip migration ( 228 d), because migration costs were included in RE.

\section{RESULTS AND DISCUSSION}

Total energy requirements for all components of reproduction for $\mathrm{PNMB}$ and St. Croix leatherbacks were $4.9 \times 10^{6} \mathrm{~kJ}$ season $^{-1}$ and $6.3 \times 10^{6} \mathrm{~kJ}_{\text {season }}{ }^{-1}$, respectively (Table 2). Round-trip migration costs dominated overall leatherback energy budgets, constituting approximately $80 \%$ of the total reproductive energy costs (Table 2, Fig. 1).

Based on the caloric content of leatherback prey and reported leatherback feeding rates (Duron 1978 [as cited in Davenport \& Balazs 1991]), a PNMB leatherback would need about 151 d to consume sufficient biomass $\left(\sim 20 \times 10^{3} \mathrm{~kg}\right.$; Table 2$)$ to meet RE, while a St. Croix leatherback (required biomass $\sim 25 \times 10^{3} \mathrm{~kg}$ ) would need about $232 \mathrm{~d}$ to meet RE. At a $150 \mathrm{~kg} \mathrm{~d}^{-1}$ feeding rate, required foraging durations to meet $\mathrm{RE}$ would extend to 245 and 426 d for PNMB and St. Croix 
Table 2. Dermochelys coriacea. Summary of energy and prey biomass requirements for PNMB (Eastern Pacific) and St. Croix (North Atlantic) leatherback turtle populations. See 'Results and discussion' for details

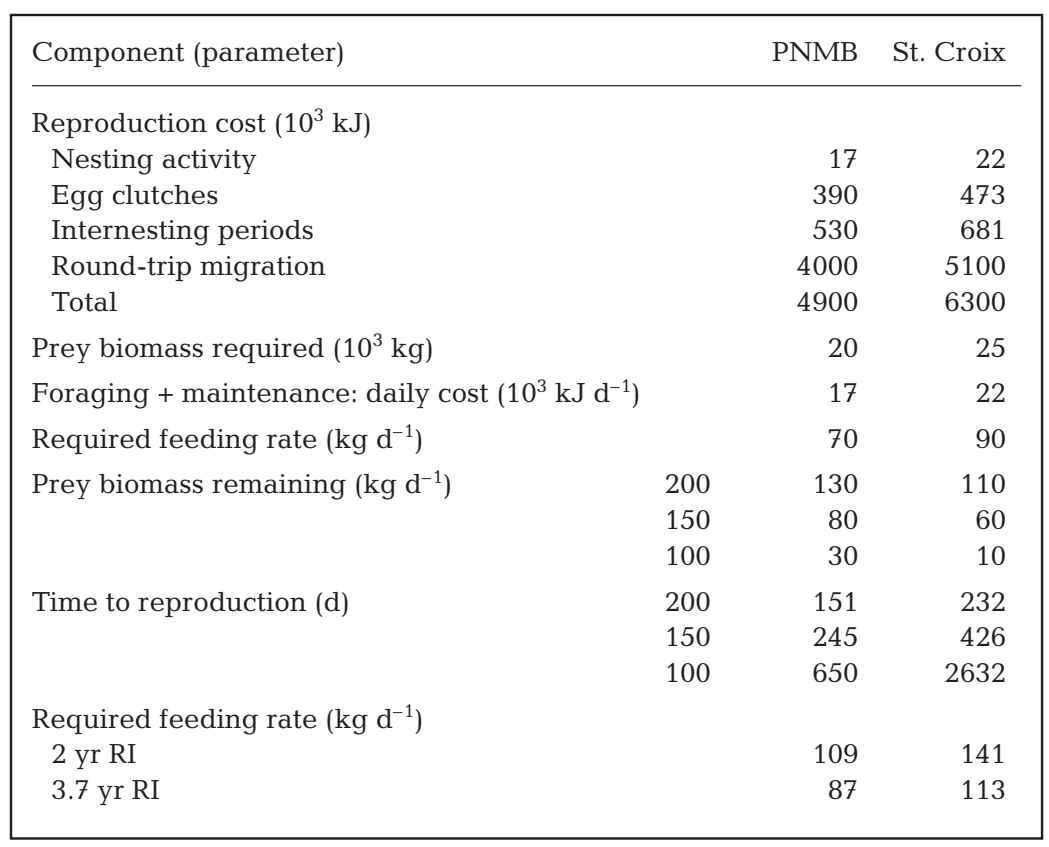

Whereas NA leatherbacks have higher absolute energy costs than EP leatherbacks (Table 2, Fig. 1), this difference is much smaller when the costs for both populations are compared relative to reproductive investment, because NA turtles lay more eggs (Tables 1 \& 2, Fig. 2). Daily feeding rates for both populations decrease as RIs lengthen (Fig. 2), but the daily feeding rate required for an EP leatherback to achieve RI $=2 \mathrm{yr}$ is about $32 \mathrm{~kg} \mathrm{~d}^{-1}$ less than that required for a 2 yr NA remigrant (Table 2, Fig. 2). Moreover, shorter RIs for EP leatherbacks (from 3.7 to 2 yr) are possible through relatively slight increases $\left(\sim 22 \mathrm{~kg} \mathrm{~d}^{-1}\right)$ in feeding rates (Table 2).

According to our leatherback energy budget estimations, total reproductive energy costs are lower, and the estimated foraging duration necessary to meet those costs shorter, for EP (PNMB) leatherbacks than for NA (St. Croix) leatherbacks. The difference in absolute energy costs can be attributed to the smaller size and lower seasonal reproductive output of EP leatherbacks (Table 1). However, RIs for these populations actually demonstrate the opposite trend, with NA leatherback RIs being almost half that of EP leatherbacks (2 vs. 3.7 yr; Table 1). Further, it is apparent that our estimates of required foraging durations dramatically underestimate the RIs observed (Boulon et al. 1996, Reina et al. 2002, Dutton et al. 2005).

Several possible explanations for these discrepancies exist. First, we might have underestimated the metabolic cost of activity and thermoregulation in cold temperate waters during migrations and foraging and this could have affected the results of our model. However, as the FMR values we used are the only metabolic rates (MRs) available for free-swimming marine turtles (Wallace et al. 2005), they are more appropriate than using nesting MRs. Additionally, according to the gigantothermy model of leatherback thermoregulation, the FMR we used in our calculations $\left(0.74 \mathrm{~W} \mathrm{~kg}^{-1}\right)$ would be adequate - if coupled with appropriate blood-flow adjustments - to maintain a body-core temperature approximately $20^{\circ} \mathrm{C}$ higher than the ambient water temperature (Paladino et al. 1990).

Second, our migratory distance inputs might have been underestimates. However, costs incurred during round-trip migration comprised approximately $80 \%$ of total reproductive energy costs for leatherbacks (Table 2, Fig. 1), so even an underestimate of migratory distances would not have changed appreciably the leatherbacks, respectively. If daily feeding rates were $100 \mathrm{~kg} \mathrm{~d}^{-1}$, a PNMB leatherback would take $650 \mathrm{~d}$ while a St. Croix leatherback would take $2632 \mathrm{~d}$ to acquire sufficient energy to meet RE (Table 2). Therefore, assuming congruent resource availability and acquisition rates for both populations, the RIs of NA leatherbacks should be from 1.5 to 4 times longer than those of EP leatherbacks. 


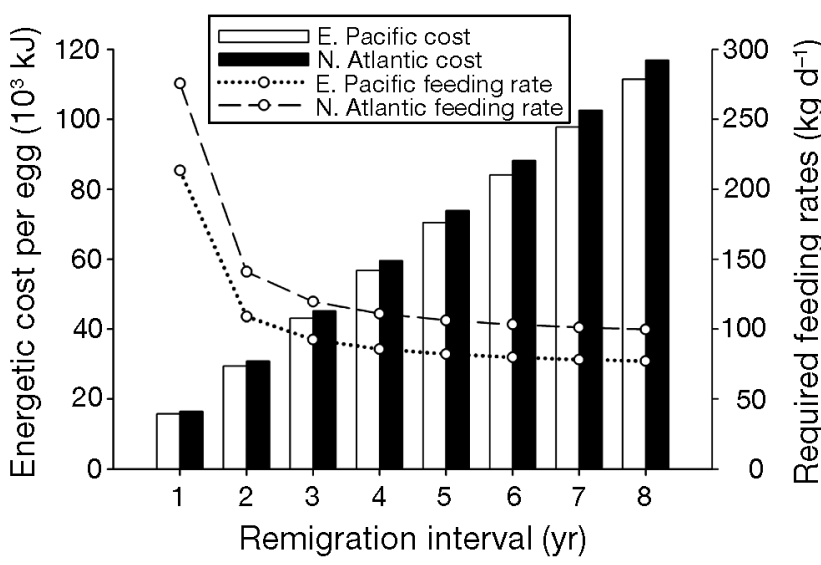

Fig. 2. Dermochelys coriacea. Estimated energy costs and feeding rate requirements for various remigration intervals of populations from Eastern Pacific (PNMB) and North Atlantic (St. Croix). Energetic cost per egg (bars) $=$ RE + foraging cost $(\mathrm{kJ})$ for a given remigration interval/egg laid per reproductive season. Feeding rates required to meet reproductive energy cost for each remigration interval (lines) $=\mathrm{RE}$ + foraging cost $(\mathrm{kJ}) /$ jellyfish energy content $\left(\mathrm{kJ} \mathrm{kg}^{-1}\right) / \mathrm{remi}-$ gration interval length (d). See 'Materials and methods' for details on model inputs

dominant influence of migration costs in the overall energy budget. Moreover, none of the leatherback telemetry studies we utilized for input values indicated that leatherbacks in either basin traveled farther than approximately $4000 \mathrm{~km}$ to reach presumed foraging grounds (Morreale et al. 1996, Eckert \& Sarti 1997, Ferraroli et al. 2004, Hays et al. 2004, James et al. 2005, G. L. Shillinger et al. unpubl. data). Additionally, our assumption of round-trip migration distance of $8000 \mathrm{~km}$ for both populations is reasonable considering (1) preliminary analyses of satellite-tracking of postnesting EP leatherbacks (G. L. Shillinger et al. unpubl. data), and (2) that James et al. (2005) reported that NA leatherbacks traveled total distances (including roundtrip migrations and movements on foraging grounds) between nesting seasons of approximately $10000 \mathrm{~km}$.

Third, we did not include the metabolic cost of movement between and among prey patches, which are crucial components of optimal foraging energetics (Mori 1998). Leatherbacks seem to occur in distinct foraging locations (James \& Herman 2001, James et al. 2005) and alter their swimming speeds and travel rates depending on whether they are moving along oceanic fronts (probable foraging) or migrating (Ferraroli et al. 2004). Variations in jellyfish abundance and distribution would alter swimming speed and travel distance inputs to the model, thereby increasing estimates of foraging energy expenditure if prey organisms were patchily distributed in different areas of the ocean. Experiments combining metabolic rate measurements and records of diving activity on foraging grounds are necessary in order to better quantify leatherback foraging energetics.

Fourth, the feeding rates we used were most probably overestimates. Climatically-driven fluctuations in oceanographic conditions (i.e. ENSO) might impact significantly resource abundance and distribution, thus increasing the required foraging time beyond the best-case estimate we present here. ENSO events are characterized by the advection of a warm-water anomaly across the Pacific toward western South America (Glantz 2001) depressing the nutrient-rich, cold upwelling off the South American Pacific coast, resulting in decreased primary productivity, altered marine and terrestrial food webs, and widespread changes in weather patterns (Chavez et al. 1999, Glantz 2001, Stenseth et al. 2002). Modeled repeated exposure to ENSO resulted in slower growth rates, delayed maturation and decreased fecundity in fishes (Harvey 2005), and oceanographic variability affects sea turtle reproduction by influencing energy acquisition, assimilation and allocation (Limpus \& Nicholls 1988, Solow et al. 2002). Furthermore, ENSO episodes result in broad-scale movements of apex predators in the Pacific Ocean, following transient foraging grounds (Lehodey et al. 1997, Worm et al. 2005), and declines in seabird (Hays 1986, Schreiber \& Schreiber 1989) and pinniped (Trillmich \& Limberger 1985) populations in the equatorial EP. To our knowledge, no data are available on abundances of gelatinous animals in the EP and their responses to ENSO-driven climate change. However, jellyfish abundances and distributions in other regions are affected by climatic forcing (Lynam et al. 2004) on broad temporal and geographic scales (Mills 2001), and productivity in areas where leatherbacks are presumed to forage in the EP (Morreale et al. 1996, Eckert \& Sarti 1997, G. L. Shillinger et al. unpubl. data) is patchy and unstable due to ENSO (Glantz 2001). Such ENSO-related decreases in primary productivity would trigger bottom-up trophic cascade effects resulting in decreased jellyfish abundances, since jellyfish and related organisms are chiefly secondary consumers. Therefore, it is doubtful that sufficiently large jellyfish aggregations consistently exist in relatively small areas to sustain the high feeding rates necessary for energy acquisition in the relatively brief periods we estimated for EP and NA leatherbacks.

Because ENSO events occur in the equatorial EP approximately every 3 to 7 yr (Chavez et al. 1999), individual EP leatherbacks will presumably face ENSO-related conditions several times during their reproductive lifespan, which could last $>20$ yr (Spotila et al. 1996). Meanwhile, the Atlantic counterpart to ENSO, the NAO, shifts from one extreme to the other 
over decades (Parsons \& Lear 2001), suggesting more consistent foraging conditions for NA leatherbacks. Indeed, chlorophyll a concentrations integrated over the years 1978 to 1986 and 1997 to 2004 encompassing the 2 most severe ENSO events of the past century (1982 to 1983 and 1997 to 1998) show apparently higher productivity in NA leatherback foraging zones (i.e. NW Atlantic Ocean off NE US and Canada, the UK, and off western Africa: Ferraroli et al. 2004, Hays et al. 2004, James et al. 2005) over these time periods than in areas where EP leatherbacks forage (off western South America: Morreale et al. 1996, Eckert \& Sarti 1997, G. L. Shillinger et al. unpubl. data) (see http:// oceancolor.gsfc.nasa.gov/SeaWiFS). Hays (2000) surmised that an individual marine turtle must meet a reproductive energy threshold before returning to her nesting beach to reproduce. Green turtles in Surinam display shorter RIs and larger clutch sizes than green turtles in Caribbean Costa Rica due to differences in available energy in the distinct diets of these 2 populations (Bjorndal 1982). Moreover, extended RIs do not result in increased reproductive output for PNMB leatherbacks (Price et al. 2004). Thus, foraging ground conditions, not increased allocation of resources to reproduction due to delaying reproduction, should influence remigration interval length. Therefore, we speculate that differential resource availability prevents EP leatherbacks from acquiring sufficient resources to match the size (carapace length and mass) and reproductive output (clutch size and RI) of NA leatherbacks (Table 1; Van Buskirk \& Crowder 1994, Boulon et al. 1996, Reina et al. 2002, Dutton et al. 2005).

Based on the results of the energy costs/feeding rates model, NA leatherbacks have higher absolute energy costs than EP leatherbacks (Table 2, Fig. 1), but the relative costs for both populations are more similar because NA turtles lay more eggs (Tables 1 \& 2, Fig. 2). The longer a female turtle from either population spends foraging at sea between nesting seasons, the more energy she must expend while harvesting sufficient resources for reproduction. For instance, turtles nesting after 2 and $8 \mathrm{yr}$ intervals at sea have the same seasonal reproductive output, but the $8 \mathrm{yr}$ remigrant expends approximately 4 times more energy than the 2 yr remigrant on foraging activities during the remigration interval (Fig. 2). Therefore, not only does delayed remigration not confer reproductive or growth advantages on individual leatherbacks (Price et al. 2004), but lengthened RIs also impose increased energetic costs. Daily feeding rates decrease as RIs lengthen because the fixed cost of reproduction is distributed over a longer period of time (Fig. 2). Obviously, the driving force in this relationship in nature is actually that feeding rates, which are influenced by resource availability, affect remigration interval length (Hays 2000). Because no data exist on feeding rates in the ocean, the remigration interval becomes a proxy for that measurement.

Most importantly, the fact that NA leatherbacks, despite having higher energy costs and higher required feeding rates, exhibit RIs half as long as their EP counterparts, indicates that resources on NA leatherback foraging grounds are probably more abundant and/or more consistent than resources on EP leatherback foraging grounds. Climate-driven fluctuations in resource availability would also explain intrapopulation variation in RIs, through different foraging conditions encountered by different individual turtles (Hays 2000). If recent climate-modeling predictions of increased frequency and intensity of El Niño events due to global warming prove accurate (Timmerman et al. 1999), EP leatherbacks could encounter continued and exacerbated resource limitation on their foraging grounds. Based on these results, we conclude that variability in foraging ground conditions in the EP related to ENSO can have considerable impacts on leatherback energy acquisition, remigration interval length and reproductive success, and thus population dynamics. This environmentally-driven resource limitation hypothesis also might have intriguing implications for life histories and population dynamics of inter-basin populations of other long-lived marine vertebrates (Schreiber \& Schreiber 1989).

Interactions with fisheries have been implicated as a principal cause of the recent decline in leatherback populations (Eckert \& Sarti 1997, Spotila et al. 2000, Lewison et al. 2004, James et al. 2005, Kaplan 2005), but the extent to which fisheries activities and associated leatherback mortality differ between basins remains poorly understood. However, leatherback bycatch rates across longline fleets in the Atlantic and Mediterranean in 2000 were actually higher than in the Pacific (Lewison et al. 2004), suggesting that fisheries pressure alone cannot explain the difference in population trends between the 2 oceans. In addition, the possibility exists that the combined threats of mortality associated with coastal fisheries off nesting beaches and poaching of nesting females on beaches (Eckert \& Sarti 1997, Troëng et al. 2004, Kaplan 2005) could represent greater risk of mortality than sources of mortality away from nesting beaches, which would affect turtles with shorter RI more than turtles with longer RI. However, assessments of mortality rates of these different threats are necessary to adequately compare risks between nesting and foraging areas. Regardless of where the mortality occurs, lengthened RIs and decreased clutch sizes - consequences of resource limitation - would decrease the lifetime reproductive success of individual EP leatherbacks, thus 
making EP populations less resilient than NA populations to currently high bycatch rates in various fisheries, including pelagic longline gear $(0.63 \%$ annually in the Pacific basin; Lewison et al. 2004) and coastal gillnets (Eckert \& Sarti 1997, Kaplan 2005). These factors may account for differences between population trends in the two oceans (Boulon et al. 1996, Spotila et al. 2000, Reina et al. 2002). Indeed, the compounded effects of anthropogenic pressures and environmental stochasticity can have severely detrimental effects on marine animal populations (Trillmich \& Limberger 1985, Hays 1986, Stenseth et al. 2002).

Decreased resource availability between reproductive seasons can lengthen RIs (Bjorndal 1982, Hays 2000), thus decreasing the seasonal and lifetime reproductive success of EP leatherbacks and increasing this population's exposure to risk of and sensitivity to fisheries-induced mortality. Given the low metabolic requirements of leatherbacks (Paladino et al. 1990, 1996, Wallace et al. 2005) it is unlikely that starvation has caused recent declines in EP populations. Therefore, while recognizing the speculative nature of our conclusions, we hypothesize that ENSO-related resource limitation might be decreasing EP leatherback reproductive success and increasing risk of incidental capture by fisheries between nesting seasons, thus causing recent (Spotila et al. 1996, 2000) and continued (Lewison et al. 2004, Kaplan 2005) declines in EP leatherback populations. While fisheries impose the more severe threat to the survival of EP leatherbacks, the compounding effects of ENSO should be taken into account in creating conservation strategies to save leatherbacks from extinction. Because the frequency and intensity of ENSO events in the EP might increase over the next few decades (Timmerman et al. 1999), management strategies for fisheries should be more conservative than they are at present, and should allow little, if any, mortality of leatherbacks if there is to be any reasonable hope for recovery of this species in the Pacific.

Acknowledgements. We thank the field biologists, Earthwatch volunteers, and PNMB Administration and Park Rangers for the collective conservation effort in PNMB. We thank P. H. Dutton, J. A. Seminoff, M. P. O'Connor, and 2 anonymous reviewers for helpful comments on this manuscript. This research was supported by the Leatherback Trust and the Betz Chair of Environmental Science endowment to Drexel University. B.P.W. was supported by a National Science Foundation Graduate Research Fellowship.

\section{LITERATURE CITED}

Arai MN, Welch DW, Dunsmuir AL, Jacobs MC, Ladouceur AR (2003) Digestion of pelagic Ctenophora and Cnidaria by fish. Can J Fish Aquat Sci 60:825-829
Avery HW, Spotila JR, Congdon JD, Fischer RU Jr, Standora EA, Avery SB (1993) Roles of diet protein and temperature in the growth and nutritional energetics of juvenile slider turtles, Trachemys scripta. Physiol Zool 66:902-925

Bjorndal KA (1982) The consequences of herbivory for the life history pattern of the Caribbean green turtle, Chelonia mydas. In: Bjorndal KA (ed) Biology and conservation of sea turtles. Smithsonian Institution Press, Washington, DC, p 111-116

Bjorndal KA (1997) Foraging ecology and nutrition of sea turtles. In: Lutz PL, Musick JA (eds) The biology of sea turtles. CRC Press, Boca Raton, FL, p 199-232

Boulon RH Jr, Dutton PH, McDonald DL (1996) Leatherback turtles (Dermochelys coriacea) on St. Croix, US Virgin Islands: fifteen years of conservation. Chelonian Conserv Biol 2:141-147

Broderick AC, Glen F, Godley BJ, Hays GC (2003) Variation in reproductive output of marine turtles. J Exp Mar Biol Ecol 288:95-109

Chavez FP, Strutton PG, Friederich GE, Freely RA, Feldman GC, Foley DG, McPhaden MJ (1999) Biological and chemical response of the equatorial Pacific to the 1997-98 El Niño. Science 286:2126-2131

Congdon JD, Dunham AE, Tinkle DW (1982) Energy budgets and life histories of reptiles. In: Gans C, Pough FH (eds) Biology of the Reptilia, Vol 13. Academic Press, New York, p 233-271

Davenport J, Balazs GH (1991) 'Fiery bodies' — are pyrosomas important items in the diet of leatherback turtles? Bull Br Herpetol Soc 37:33-38

Dunham AE, Grant BW, Overall KL (1989) Interfaces between biophysical and physiological ecology and the population ecology of terrestrial vertebrate ectotherms. Physiol Zool 62:335-355

Duron M (1978) Contribution à l'étude de la biologie de Dermochelys coriacea (Linné) dans les Pertuis Charentais. Thèse, Université Bordeaux

Dutton DL, Dutton PH, Chaloupka M, Boulon RH (2005) Increase of a Caribbean leatherback turtle Dermochelys coriacea nesting population linked to long-term nest protection. Biol Conserv 126:186-194

Eckert SA (2002) Swim speed and movement patterns of gravid leatherback sea turtles (Dermochelys coriacea) at St. Croix, US Virgin Islands. J Exp Biol 205:3689-3697

Eckert SA, Sarti L (1997) Distant fisheries implicated in the loss of the world's largest leatherback nesting population. Mar Turt Newsl 78:2-7

Ferraroli S, Georges JY, Gaspar P, Maho YL (2004) Where leatherback turtles meet fisheries. Nature 429:521-522

Glantz MH (2001) Currents of change: impacts of El Niño and La Niña on climate and society, 2nd edn. Cambridge University Press, Cambridge

Harvey CJ (2005) Effects of El Niño events on energy demand and egg production of rockfish (Scorpaenidae: Sebastes): a bioenergetics approach. Fish Bull 103:71-83

Hays C (1986) Effects of the 1982-83 El Niño on Humboldt penguin colonies in Peru. Biol Conserv 36:169-180

Hays GC (2000) The implications of variable remigration intervals for the assessment of population size in marine turtles. J Theor Biol 206:221-227

Hays GC, Houghton JDR, Myers AE (2004) Pan-Atlantic leatherback turtle movements. Nature 429:522

James MC, Herman TB (2001) Feeding of Dermochelys coriacea on medusae in the northwest Atlantic. Chelonian Conserv Biol 4:202-205

James MC, Ottensmeyer CA, Myers RA (2005) Identification of high-use habitat and threats to leatherback sea turtles 
in northern waters: new directions for conservation. Ecol Lett 8:195-201

Jenouvrier S, Barbraud C, Cazelles B, Weimerskirch H (2005) Modelling population dynamics of seabirds: importance of the effects of climate fluctuations on breeding proportions. Oikos 108:511-522

Kaplan IC (2005) A risk assessment for Pacific leatherback turtles (Dermochelys coriacea). Can J Fish Aquat Sci 62: 1710-1719

Lehodey P, Bertignac M, Hampton J, Lewis A, Picaut J (1997) El Niño Southern Oscillation and tuna in the western Pacific. Nature 389:715-718

Lewison RL, Freeman SA, Crowder LB (2004) Quantifying the effects of fisheries on threatened species: the impact of pelagic longlines on loggerhead and leatherback sea turtles. Ecol Lett 7:221-231

Limpus CJ, Nicholls N (1988) The southern oscillation regulates the annual numbers of green turtles (Chelonia mydas) breeding around northern Australia. Aust J Wildl Res 15:157-161

Lynam CP, Hay SJ, Brierley AS (2004) Interanual variability in abundance of North Sea jellyfish and links to the North Atlantic Oscillation. Limnol Oceanogr 49:637-643

Malej A, Faganeli J, Pezdič J (1993) Stable isotope and biochemical fractionation in the marine pelagic food chain: the jellyfish Pelagia noctiluca and net zooplankton. Mar Biol 116:565-570

Mills CE (2001) Jellyfish blooms: are populations increasing globally in response to changing ocean conditions? Hydrobiologia 451:55-68

Mori Y (1998) The optimal patch use in divers: optimal time budget and the number of dive cycles during bout. J Theor Biol 190:187-199

Morreale SJ, Standora EA, Spotila JR, Paladino FV (1996) Migration corridor for sea turtles. Nature 384:319-320

Owens DW (1980) The comparative physiology of sea turtles. Am Zool 209:549-563

Paladino FV, O'Connor MP, Spotila JR (1990) Metabolism of leatherback turtles, gigantothermy, and thermoregulation of dinosaurs. Nature 344:858-860

Paladino FV, Spotila JR, O'Connor MP, Gatten RE Jr (1996) Respiratory physiology of adult leatherback turtles (Dermochelys coriacea) while nesting on land. Chelonian Conserv Biol 2:223-229

Parsons LS, Lear WH (2001) Climate variability and marine ecosystem impacts: a North Atlantic perspective. Prog Oceanogr 49:167-188

Price ER, Wallace BP, Reina RD, Spotila JR, Paladino FV, Piedra R, Velez E (2004) Size, growth, and reproductive output of adult female leatherback turtles Dermochelys coriacea. Endang Species Res No. 5:1-8

Editorial responsibility: Howard I. Browman (Associate Editor-in-Chief), Storebø, Norway
Reina RD, Mayor PA, Spotila JR, Piedra R, Paladino FV (2002) Nesting ecology of the leatherback turtle, Dermochelys coriacea, at Parque Nacional Marino Las Baulas, Costa Rica: 1988-1989 to 1999-2000. Copeia 2002:653-664

Reina RD, Abernathy KJ, Marshall GJ, Spotila JR (2005) Respiratory frequency, dive behavior and social interactions of leatherback turtles, Dermochelys coriacea, during the inter-nesting interval. J Exp Mar Biol Ecol:316:1-16

Schmidt-Nielsen K (1997) Animal physiology: adaptation and environment, 5th edn. Cambridge University Press, Cambridge

Schreiber EA, Schreiber RW (1989) Insights into seabird ecology from a global 'natural experiment'. Natl Geogr Res 5:64-81

Solow AR, Bjorndal KA, Bolten AB (2002) Annual variation in nesting numbers of marine turtles: the effect of sea surface temperature on re-migration intervals. Ecol Lett 5: 742-746

Spotila JR, Dunham AE, Leslie AJ, Steyermark AC, Plotkin PT, Paladino FV (1996) Worldwide population decline of Dermochelys coriacea: are leatherback turtles going extinct? Chelonian Conserv Biol 2:209-222

Spotila JR, Reina RD, Steyermark AC, Plotkin PT, Paladino FV (2000) Pacific leatherback turtles face extinction. Nature 405:529-530

Stenseth NC, Mysterud A, Hurrell JW, Chan KS, Lima M (2002) Ecological effects of climate fluctuations. Science 297:1292-1296

Timmerman A, Oberhuber J, Bacher A, Esch M, Latif M, Roeckner E (1999) Increased El Niño frequency in a climate model forced by future greenhouse warming. Nature 398:694-697

Trillmich F, Limberger D (1985) Drastic effects of El Niño on Galápagos pinnipeds. Oecologia 67:19-22

Troëng S, Chacón D, Dick B (2004) Possible decline in leatherback turtles Dermochelys coriacea nesting along the coast of Caribbean Central America. Oryx 38:395-403

Van Buskirk J, Crowder LB (1994) Life history variation in marine turtles. Copeia 1994:66-81

Wallace BP, Williams CL, Paladino FV, Morreale SJ, Lindstrom LT, Spotila JR (2005) Bioenergetics and diving activity of internesting leatherback turtles (Dermochelys coriacea) at Parque Nacional Marino Las Baulas, Costa Rica. J Exp Biol 208:3873-3884

Wikelski M, Thom C (2000) Marine iguanas shrink to survive El Niño. Nature 403:37-38

Worm B, Sandow M, Oschiles A, Lotze HK, Myers RA (2005) Global patterns of predator diversity in the open oceans. Science 309:1365-1369

Zug GR, Parham JF (1996) Age and growth in leatherback turtles, Dermochelys coriacea, (Testudines: Dermochelyidae): a skeletochronological analysis. Chelonian Conserv Biol 2:244-249

Submitted: October 10, 2005; Accepted: December 13, 2005 Proofs received from author(s): July 11, 2006 